\title{
包接化合物の構造と反応性 —シクロデキストリン包接化合物を中心にして—
}

Takaji FUJIWARA : Structure and Reactivity of Inclusion Complexes-Cyclodextrin Inclusion Compounds-

Based on X-ray single crystal analyses of $\alpha-, \beta-$, and $\gamma$-cyclodextrins inclusion compounds, relation between structure and reactivity is demonstrated, especially focusing on molecular structure of the inclusion complexes. [J. Cryst. Soc. Jpn. 24, 54 (1982)].

\section{1. はじめに}

尿素, シクロファン，クラウンエーテルやイオノフォア等のホスト分子がゲスト分子をと り込み包接化合物を生成することが知られているが，ここにとりあげたシクロデキストリン (CD と略) はホスト分子としてその分子構造が特異的なこと，及びゲスト分子が稀がスから 鎖状及び環状有機化合物にいたる広範囲の物質であることから, 1891 年に発見されて以来, 1950 年代より CD 包接化合物の化学研究が盛んとなり，1960 年代よりX線単結晶構造解析 が本格的に開始され，既に 50 種類に及ぶ $\mathrm{CD}$ 包接化合物の構造が明らかにされている. CD の化学, 分子構造及び利用について優れた成書 ${ }^{122}$ や総説 ${ }^{3 \sim 5}$ があるので一読を推める.ここ では最近の構造解析の報文をもとに，分子構造に立脚して CD 包接化合物の構造と包接化反 応との関連をさぐってみる. $\mathrm{CD}$ 包接化合物構造解析の目的は 2 つあ. 第一はフェニルェ ステル類の加水分解で代表される反応の，CDによる触媒作用を解明することである．この 反応は CD・基質包接複合体の生成が第一段階で, 疎水性の CD の鍵穴にいかに基質とい5 鍵がうまくはまるかといら点で或る種の酵素反応のモデルとなる．第二にデンプンのアミロ 一ス部分は,グルコピラノース ( $\mathrm{G}$ と略) 単位が第 1 図（a)に示した ${ }^{4} \mathrm{C}_{1}$ いす型立体配座を とり 6 単位で 1 回転して $8 \AA ̊$ 進む左巻らせん構造をしている.この中にヨウ素が包接されて 青色を呈するョウ素-デンプン反応において，デンプンの酵素分解物である CD とヨウ素, ヨウ素イオンとの包接化合物の構造解析はこの反応のモデル研究として重要である.

\section{2. $\mathrm{CD}$ の基本分子構造}

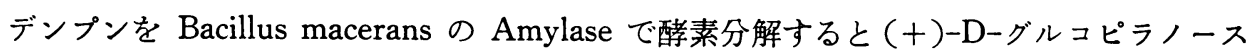
単位 (第 1 図) が $\mathrm{n}$ 個 $\alpha-1,4$-結合した大環状オリゴ糖が生成する. n が 6,7 及び 8 のものが $\alpha-, \beta-, \gamma-C D$ と呼ばれよく知られている．分子はドーナッ状，植木鉢状で分子内部の空洞に 種々のゲスト分子を包接する. 第 1 表に分子の寸法物性等を示す. CD 包接化合物は CD の 水溶液の状態から生成されるので，ゲスト分子のとり込まれていない“空の CD”とは水が 空洞の内外に存在する “CD 水和物” のことであり, 包接化合物の構造を研究するらえで最 も重要である。これまでの $\alpha-, \beta-, \gamma-C D$ 包接化合物の X線解析の結果からは, $G$ 単位はすべ 


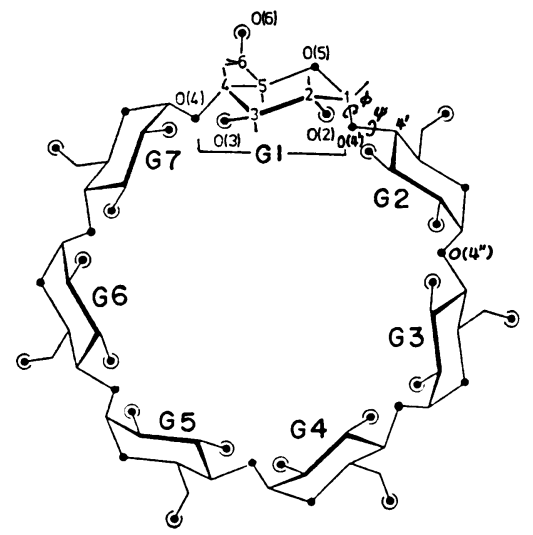

(a)

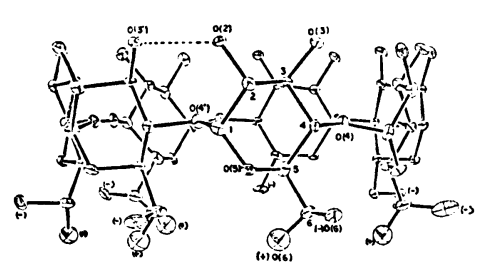

(c)

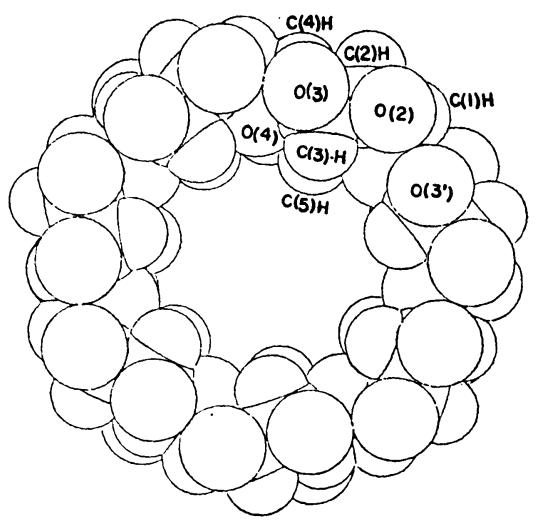

(b)

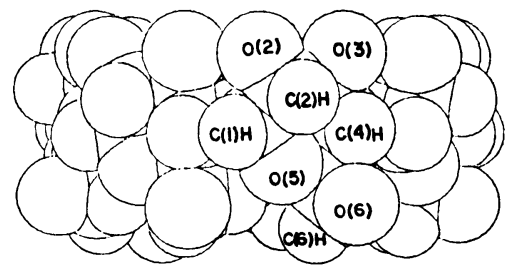

(d)

第 1 図（a） $0(2), 0(3)$ 側より見た $\beta-C D$ の構造（黒丸は酸素原子，二重丸は水酸基）

（b ） a ) の空間充垻因（水酸基の水素原子は省略）

(c) 側面より見た $\beta-C D$ 構造 $((+),(-)$ は $0(6)$ の立体配座, 点線は水素結合)

(d) b )を側面より描いた図

第1表 $\mathrm{CD}$ の物性と分子構造データ 5,36$)$

\begin{tabular}{|c|c|c|c|c|c|c|c|c|c|c|c|c|}
\hline $\mathrm{CD}$ & $\mathrm{n}$ & $\mathrm{Mw}_{\mathrm{w}}$ & $\mathrm{S}$ & {$[\alpha]_{4}^{25}$} & $\begin{array}{c}\mathrm{r} \\
(\AA)\end{array}$ & $\begin{array}{c}\omega \\
(\AA)\end{array}$ & $\begin{array}{c}\mathrm{h} \\
(\AA)\end{array}$ & $\begin{array}{c}\theta \\
\left(^{\circ}\right)\end{array}$ & $\begin{array}{c}\phi \\
\left(^{\circ}\right)\end{array}$ & $\begin{array}{c}\phi \\
\left(^{\circ}\right)\end{array}$ & $\begin{array}{c}\mathrm{D}_{1} \\
(\AA)\end{array}$ & $\begin{array}{l}\mathrm{D}_{2} \\
(\AA)\end{array}$ \\
\hline$\alpha-$ & 6 & 972 & 14.5 & 150.5 & $4.7-5.2$ & 14.6 & \multirow{3}{*}{$7.9-8.0$} & 119.0 & 166 & -169 & 4.23 & 3.00 \\
\hline$\beta-$ & 7 & 1135 & 1.85 & 162.5 & $6.0-6.4$ & $15.4\}$ & & 117.7 & 169 & -172 & 4. 39 & 2.86 \\
\hline$\gamma-$ & 8 & 1297 & 23.2 & 177.4 & $7.5-8.3$ & 17.5 & & 112.6 & 165 & -169 & 4. 48 & 2.81 \\
\hline
\end{tabular}

$\mathrm{n}: \mathrm{G}$ 単位の数, $\mathrm{S}:$ 水に対する溶解度 $\left(\mathrm{g} / 100 \mathrm{~m} l \mathrm{H}_{2} \mathrm{O}\right), \mathrm{r}, \omega, \mathrm{h}: \mathrm{CD}$ の内径, 幅, 厚さ, $\theta:$ グル コシド結合角 $\angle C\left(1^{\prime}\right)-0(4)-C(4), \phi, \phi$ : 次に定義するねじれ角で大環状構造を示すパラメター, $0(4) \cdots C(1)-0\left(4^{\prime}\right)-C\left(4^{\prime}\right), C(1)-0\left(4^{\prime}\right)-C\left(4^{\prime}\right) \cdots 0\left(4^{\prime \prime}\right)$; 隣接の $\mathrm{G}$ 単位を'又は" 又゙つけて示す, $\mathrm{D}_{1}$ : 隣接 $\mathrm{G}$ 単位間の $0(4) \cdots 0\left(4^{\prime}\right)$ の距離, $\mathrm{D}_{2}$ : 隣接 $\mathrm{G}$ 単位間の $0(2) \cdots 0\left(3^{\prime}\right)$ の距離で分子内水素結合を 示す.

ていす型構造 ${ }^{4} \mathrm{C}_{1}$ をしており,グルコシド酸素原子 $\mathrm{O}(4)$ は全て同一平面上にある. $\mathrm{CD}$ 内部 の壁はエーテル性を示す $\mathrm{O}(4)$ 原子と，水素原子 C(3)- $\mathrm{H}, \mathrm{C}(5)-\mathrm{H}$ によって囲まれた疎水性 雾囲気を形成している。一方植木鉢形 $\mathrm{CD}$ の上部入口 (head) には 2 級水酸基 $>\mathrm{CH}-\mathrm{O}(2) \mathrm{H}$ と $>\mathrm{CH}-\mathrm{O}(3) \mathrm{H}$ があり, 底部には 1 級水酸基 $-\mathrm{CH}_{2}-\mathrm{O}(6) \mathrm{H}$ が位置するので, ホスト $\mathrm{CD}$ 分子 の両入口は親水性である. $\mathrm{G}$ 単位の $\mathrm{C}(2), \mathrm{C}(3), \mathrm{C}(5), \mathrm{O}(5)$ 原子も又一つの平面上にのるの で，これと $\mathrm{O}(4)$ 平面とのなす二面角は植木鉢の傾斜を表わす。この二面角は $90^{\circ}$ より小さ く, $\mathrm{CD}$ は $\mathrm{O}(2), \mathrm{O}(3)$ 原子側で広く, $\mathrm{O}(6)$ 原子側で狭くなっている. 各 $\mathrm{G}$ 単位間には $\mathrm{O}(2)$ 
…O $\left(3^{\prime}\right)$ 水素結合がかかり（第 1 図 (c)), 歪の無い $\mathrm{CD}$ 大環状構造を形成している. $\mathrm{O}(2) \cdots$ $\mathrm{O}\left(3^{\prime}\right)$ の水素結合には方向性は認められない. 1 級水酸基は $\mathrm{C}(5)-\mathrm{C}(6)$ 結合まわりの自由回 転により， $\mathrm{C}(6)-\mathrm{O}(6)$ 結合が $\mathrm{CD}$ 大円環の外側につき出ているもの即ちねじれ角 $\mathrm{O}(5)-\mathrm{C}(5)$ $-\mathrm{C}(6)-\mathrm{O}(6)$ が (一) gauche の配向と, 内側に向いている $(+)$ gauche をとるものとの 2 種 類第 1 図 (c) が見い出されている. $\mathrm{O}(6)$ が内側に向いている場合はゲストの極性基と水素 結合をしており，外側に向いた場合は隣の CD との間で直接或いは水を介した水素結合を している場合が多い.この二つの配向はまた $\mathrm{O}(6)$ 原子の disorder としてよく観測される. $\mathrm{CD}$ の 2 級水酸基の $\mathrm{pKa}$ は約 12 であるから， $\mathrm{pH}=12$ ではその約 $50 \%$ が陰イオン $>\mathrm{CH}-\mathrm{O}^{-}$ となっており, 強アルカリ性ではすべて陰イオンとなっている.一方 1 級水酸基はアルコー ル性を示し， $\mathrm{pKa}$ は大きく，ほとんど $-\mathrm{CH}_{2} \mathrm{OH}$ のままで存在する. $\mathrm{CD}$ 包接化合物の構造 では CD 内部の疎水性部分にゲスト分子の蹯水性部分がファンデルワールス接触をしている. ゲスト分子の極性基は CD の 1 級及び 2 級水酸基と直接或いは水を介した水素結合で結ばれ ることが多い．水は CD の 1 級及び 2 級水酸基の近くにあり，まわりの CD を水素結合で結 んで結晶構造安定化の役割を果たしている．CD の空洞に比較的小さなゲスト分子が包接さ れている時は,ゲスト分子は空洞内で定った位置を占有せずいくつかの位置に統計的に分布 (disorder) することが多い.ゲスト分子の形状，大きさによってホスト CDのパッキング(第 2 図)がある程度規定される. 小さなゲスト分子では空の $\mathrm{CD}$ と同じ“かご型構造” 7 9, 12 14, 25 28,35) をとる.これは CD 大円環の中心から離れた位置に 2 回らせん軸があり，かつ0(4) 平面がらせん軸に対して傾いているときにできる，CD 分子の両端をお互いに封をし合った 構造である，次にらせん軸が $0(4)$ 平面と直交し，分子軸からずれているときには“層状構 造”をとる.これは $\alpha-\mathrm{CD}$ とベンゼン誘導体との分子複合体 ${ }^{20 \sim 22)}$ によくみられる.C 分子 が一方向に無限に積重なった “筒型構造” 15 19, 28 24, 29,36) が CD とアニオンや細長いゲスト 分子との包接化合物によくみられる.

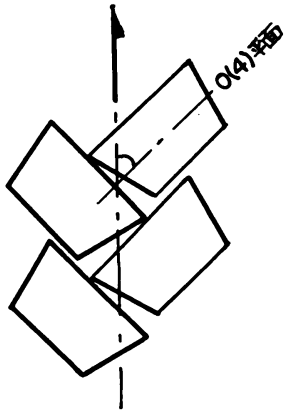

(a)

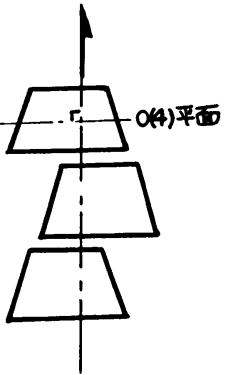

(b)

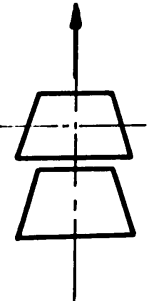

$(\mathrm{C}-1)$

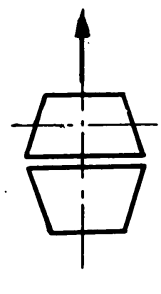

$(\mathrm{C}-2)$

第 2 図 $\mathrm{CD}$ のパッキング様式
(a) かご型構造
(b) 層状構造
(c) 筒型構造 (1) head-to-tail. 2) head-to-head)

\section{3. 空のシクロデキストリンの構造}

$3.1 \alpha-\mathrm{CD} \cdot$ 水和物の構造 結晶化の条件により 3 種類の $\alpha-\mathrm{CD}$ ・水和物の 結 晶（第 2 表）が見出されている. I 型》は最も普通に得られる型でII 型8) は結晶化時に急冷した時, III型9) は $\alpha-\mathrm{CD} \cdot \mathrm{Ba}^{2+}$ 複合体を作る目的で $1.2 \mathrm{MBaCl}_{2}$ を含む $\alpha-\mathrm{CD}$ 水溶液から目的に反し

24. 1-56 
第 2 表 $\mathrm{CD}$ ・水和物の結晶学的データ

\begin{tabular}{|c|c|c|c|c|c|c|c|c|c|}
\hline \multirow{2}{*}{$\mathrm{CD}$ の種類 } & \multirow{2}{*}{ 型 } & \multirow{2}{*}{ 空間 群 } & \multicolumn{4}{|c|}{ 格 子 定 数 } & \multicolumn{3}{|c|}{ 水の数(水の占める場所) } \\
\hline & & & a & $\mathrm{b}$ & c $(\AA)$ & $\beta^{\circ}$ & 空洞内 & 空洞外 & 計 \\
\hline \multirow{3}{*}{$\alpha-C D^{7 \sim 9)}$} & I & \multirow{3}{*}{$\mathrm{P} 2{ }_{1} 2_{1} 2_{1}$} & 14.856 & 33.991 & 9.517 & & 2 & 4 & 6 \\
\hline & II & & 13.70 & 29.35 & 11.92 & & 1 & 5 & 6 \\
\hline & III & & 14.356 & 37.538 & 9.400 & & $2.57(4)$ & 5 & 7.57 \\
\hline \multirow{2}{*}{$\beta-C D^{25 \sim 26)}$} & I & \multirow{2}{*}{$\mathrm{P} 2_{1}$} & 21.29 & 10.33 & 15.10 & 112.4 & $7.0(8)$ & $4.9(8)$ & 12 \\
\hline & II & & 21.085 & 10.212 & 15.123 & 111.66 & $6.5(8)$ & $5.0(7)$ & 11.5 \\
\hline$\gamma-\mathrm{CD}^{35)}$ & & $\mathrm{P} 2_{1}$ & 20.253 & 10.494 & 16.892 & 105.32 & $12(13)$ & $5(6)$ & 17 \\
\hline
\end{tabular}

て $\alpha-\mathrm{CD}$ ・水和物が得られたものである. I 型 (第 3 図) では全部で 6 個の結晶水のらち 2 個 (A, B) は空洞内の定位置にある. 水 $\mathrm{A}$ は水 B及び $\mathrm{G} 5$ の $\mathrm{O}(6)$ と水素結合している. $\alpha-\mathrm{CD}$ の環状構造は G5 のところで大きくくずれていて, G間の $\mathrm{O}(2) \cdots \mathrm{O}\left(3^{\prime}\right)$ 水素結合がこの間で 切れている. 更に G1 と G5 の O (6) が CD 環の内側に向き水 $\mathrm{A}$ との間に水素結合を形成する. 他の $\mathrm{G}$ 単位の $\mathrm{O}(6)$ はすべて $\mathrm{CD}$ 環の外側を向いていて， $\mathrm{G}$ 単位は安定なコンフォメーショ ンをとっている. G5 の䨤はねじれ角 $\phi, \phi$ (第 1 図,第 1 表) で表現したュンフォメーション エネルギーの計算から，歪のない大環状構造をとるときより $1.5 \sim 6 \mathrm{kcal} / \mathrm{mol}$ 不安定である といら. 空洞にゲスト分子を包接した時の $\alpha-\mathrm{CD}$ 分子は歪のない大環状構造をとることから， 環の歪によるエネルギーを有するI 型の結晶はゲストを包接する推進力を内包している. 次 にII 型の構造はI 型の水Bが欠けている他は 本質的には I 型と変らない， III 型は I, II 型 と全く異なり， $\alpha$-CD は無昰大環状構造をし ていること及び第 4 図に示したよらに空洞内 では 4 箇所に実質 2.57 分子の水が統計的に 分布している. 従ってこの空洞内の水は水分 子間で十分な水素結合が出来ないので, 活性

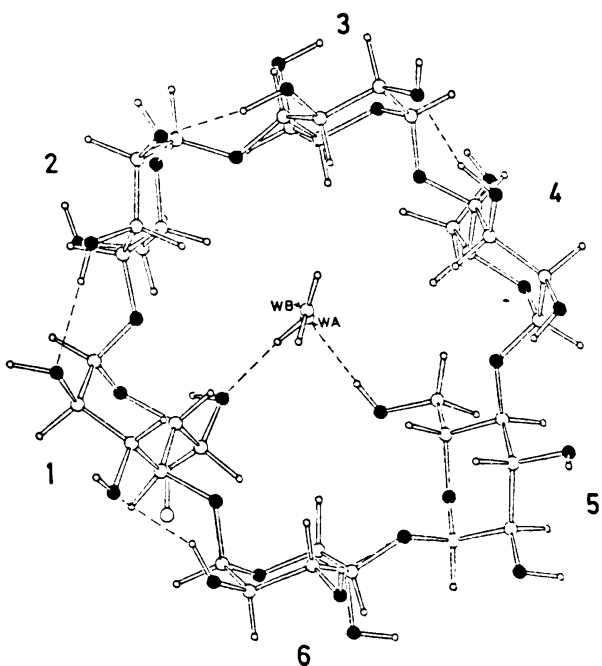

第3 図 $\alpha-\mathrm{CD}$ ・水和物 (I) の分子構造.
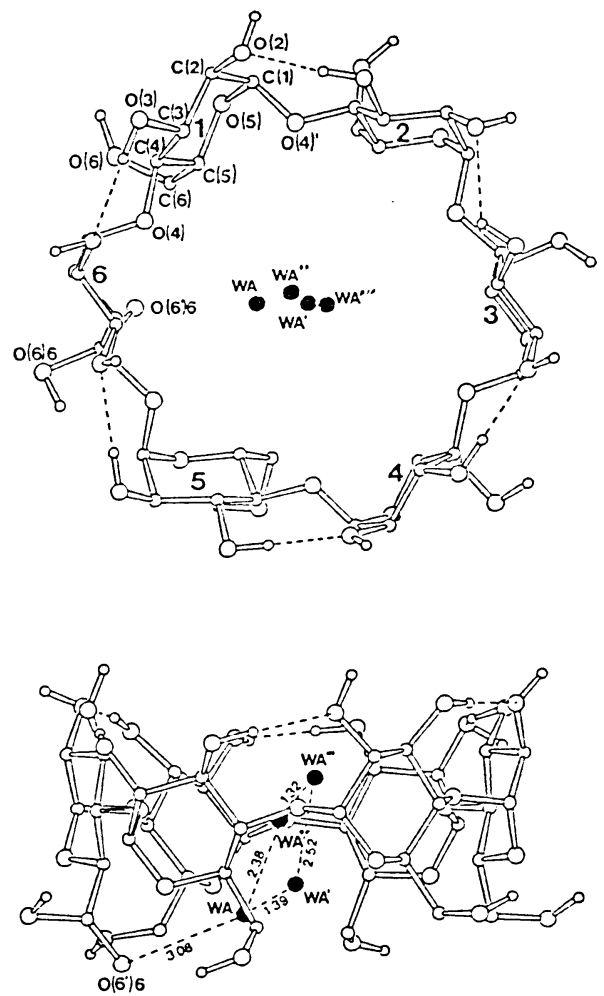

第 4 图 $\alpha-\mathrm{CD}$ ・水和物 (III) の分子構造. 


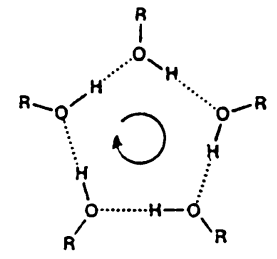

a)

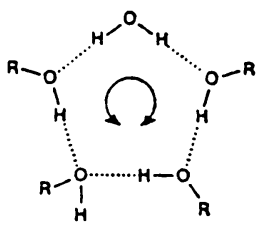

b)

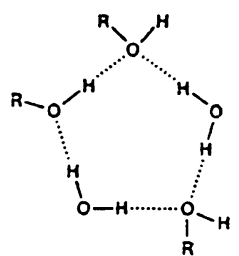

c)

第 5 図 環状水素絬合

a) homodromic b) antidromic c) heterodromic

化状態にあり，CD 環の垔は無いが水が活性化されている状態も又ゲスト分子をとり込む時 の原動力となると考える. 空洞外の水及び $\mathrm{CD}$ の $\mathrm{O}(6) \mathrm{H}, \mathrm{O}(2) \mathrm{H}, \mathrm{O}(3) \mathrm{H}$ 間の水素結合様式 を中性子回折と X線の差フーリェから求めた $\mathrm{H}$ の位置をもとに詳細に検討すると, 水を含む 5 6 員環の水素結合形成 ${ }^{10 \sim 11)}$ (第 5 図) が見られ，O-H $\cdots>\mathrm{O}$ が一方向であるもの (homodromic), 逆回りのもの (antidromic), ランダムなもの (heterodromic) に分類出来ること, 前二者の系の全エネルギーは個々の水素結合の和より $2 \sim 4 \mathrm{kcal} /$ 環 低いことから, 水素結合 の環化による協同効果を指摘している， $\alpha-\mathrm{CD}$ ・水和物にみられる水の構造は四面体配位の 氷の構造からはかなり歪んでいるものが多い.

$3.2 \beta-C D \cdot$ 水和物の構造 $\beta-C D$ ・水和物も 2 種の結晶が見出されている. I 型 ${ }^{25)}$ (第 6 図）は水溶液より普通に析出する結晶で, II 型 ${ }^{26)}$ は $\beta-C D$ の高温高濃度水溶液を急冷 して得られ，空気中で徐々にI型に変化する ことから準安定な結晶であると言える．空間 群は $\mathrm{P} 22_{1}$ (第 2 表) で $\alpha-\mathrm{CD}$ の $\mathrm{P} 2{ }_{1} 2_{1} 2_{1}$ と異な るけれども, 1 本の 2 回らせん軸により関係づ けられる CD 分子の配列は同じで，かご型構 造をしている. 空洞内の水は8 箇所に disor$\operatorname{der} し て お り ， \alpha-C D \cdot$ 水和物の型と同じよ うに, $\beta-\mathrm{CD}$ は無歪大環状構造をしているが， 空洞内にはエンタルピーに富む水を貯えてお り， $\beta-\mathrm{CD}$ がゲスト分子を包接する時のエネ ルギー源となっている. II 型26)は空洞内の水 の位置, 空洞外の水の数が多少異なることを 除くと，構造はI 型と同じである．然し低温

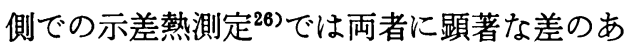
ることがわかっている。

$3.3 \gamma-\mathrm{CD} \cdot$ 水和物の構造 $\gamma-\mathrm{CD} \cdot$ 水和 物の構造 ${ }^{85)}$ は前述した $\alpha-C D$ のII 型, $\beta-\mathrm{CD}$ の I , II 型と同じょうに無歪環状構造をとる $\gamma-\mathrm{CD}$ の空洞に実質 12 分子の水が 13 箇所に
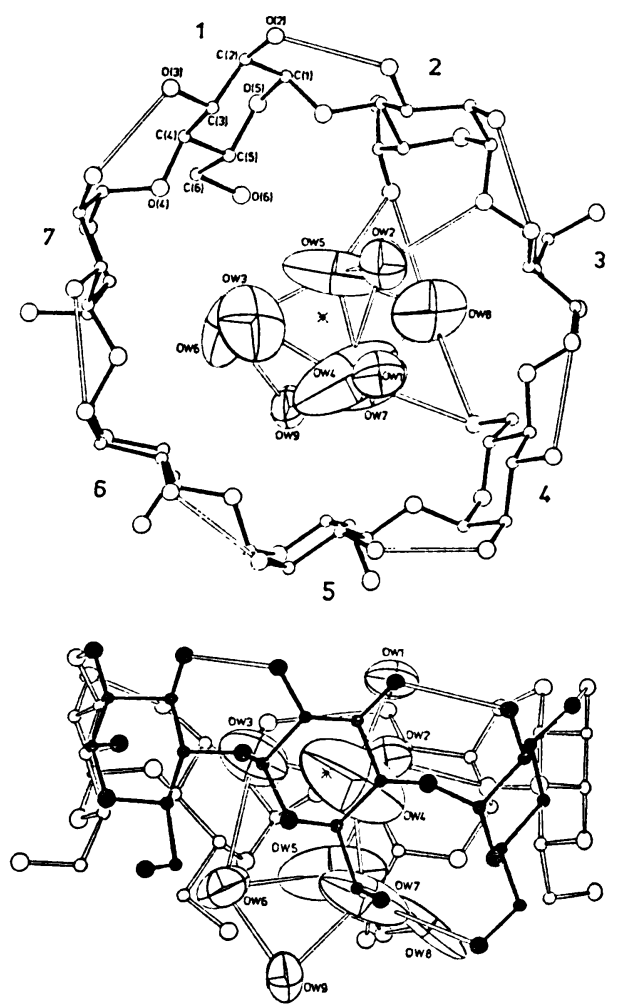

第 6 图 $\beta-C D$ - 水和物 (I) の分子構造 OW は空洞内の水 
disorder して存在する. 分子の立体図より判断すると, 空洞内の水は $\beta-C D ・$ 水和物で見ら れた多くの disorder 水の集合ではないようで, 活性化状態の水による包接推進力は小さいの ではないだろらか，CD 環が大きくなると環状構造も柔軟性に富むと思われ，1つの $\mathrm{G}$ 単位 には分離不能な disorder が見出されている. 空間群は $\mathrm{P} 21$ (第 2 表)で 2 回らせん軸によっ て関係づけられた $\gamma-\mathrm{CD}$ はかご型構造をしており，空の $\mathrm{CD}$ の構造は $\alpha-, \beta-, \gamma-\mathrm{CD}$ 共すべ てがかご型構造で, 空洞内部に水を閉じこめている。

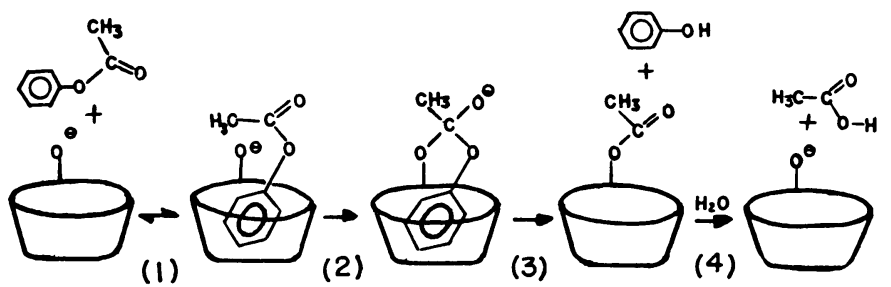

第 7 図 酢酸フェニルの開裂反応径路.

1）包接化合物生成 2）四面体中間体生成

3) 開裂

4) 加水分解

\section{CD の触媒作用と包接化合物の構造}

酢酸フェニルェステルの開裂反応 (第 7 図) は, $\mathrm{CD}$ の二級水酸アニオンが基質のカルボ ニル炭素を求核攻撃し四面体中間体を経由してアシル CD とフェノールを生成する段階が律
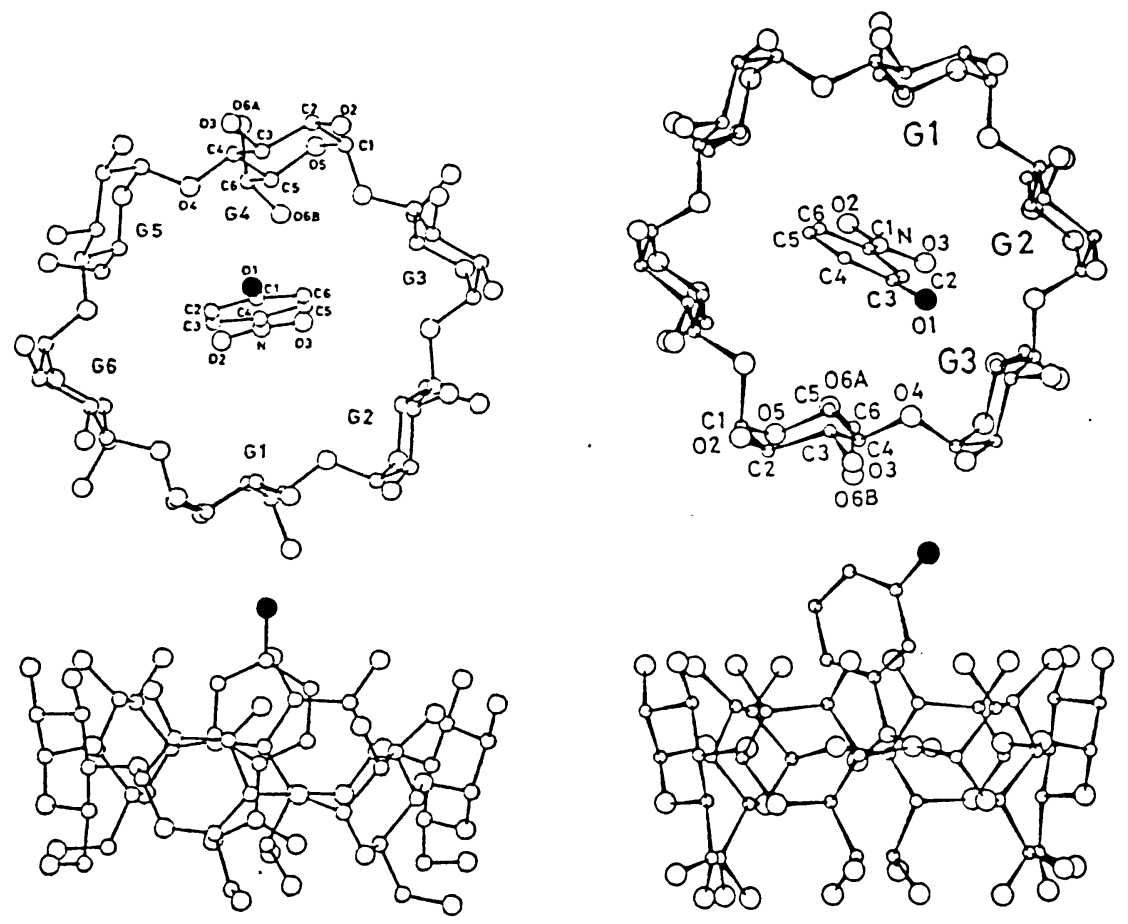

(a)

(b)

第 8 图 $\alpha-\mathrm{CD}$ ・ニトロフェノルの分子構造.

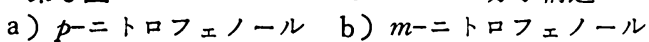

黒丸はフェノール OH 基 
速で, 基質の $m$-位及び $p$-位を $t$-ブチル基で置換した場合の反応速度を $\mathrm{CD}$ 非存在下の時を 基準にして比較すると， $m$-体は $p$-体より 200 倍も反応が加速 ${ }^{6)}$ されることから， CD に包 接された $m$-体のカルボニル炭素は， $p$-体よりも CD の二級水酸アニオンに, より攻撃され 易い位置即ち立体的に好都合な位置にあると考えられる.この反応モデルとして酢酸フェニ

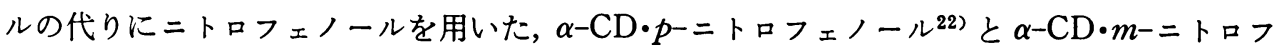

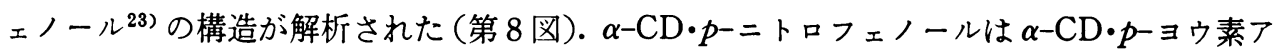

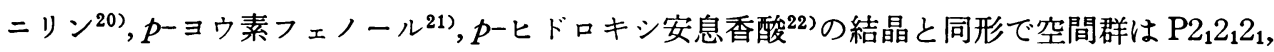
層状構造をしている.フェノール $\mathrm{OH}$ 基やアミノ基は $\mathrm{CD}$ の $\mathrm{O}(2), \mathrm{O}(3)$ 側から環外につき 出し， $p$-置換ベンゼン残基が空洞内に包接されている. 面白いことに $\alpha-C D$ 空洞内でのべ

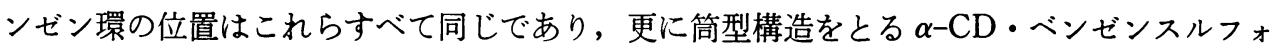
ン酸 $\mathrm{Na}$ 塩 ${ }^{18)}$ や $\alpha-\mathrm{CD}$ ・メチルオレンジ $\mathrm{Na}$ 塩 ${ }^{17)}$ のフェニルスルフォン酸残基にみられる $\alpha-\mathrm{CD}$ とベンゼン環の相対位置と同じである. 従っ て $\alpha-\mathrm{CD}$ にベンゼン環が包接される場合は， $\alpha-\mathrm{CD}$ のパッキングとは無関係な都合の良い場所のあるこ とを示している.この場合には $\alpha-\mathrm{CD}$ の $\mathrm{C}(5)-\mathrm{H} に$ よって囲まれて出来る最も狭い空隙で， $\alpha-\mathrm{CD}$ の C (5)-H とベンゼン環のHとが相互作用するところ迄 奥深く入り込んでいる。ベンゼンのよらに平たい分 子が $\alpha-\mathrm{CD}$ に包接されると, $\mathrm{O}(4)$ の平面性を保っ たままで $\alpha-\mathrm{CD}$ の大円環がゲストの形に応じて第 9 図のように变形することがわかっている，一方 $\alpha-$ $\mathrm{CD} \cdot m$-ニトロフェノール (23) は筒型構造をとり， $\alpha-$ $\mathrm{CD}:$ ゲスト $=1: 2$ でゲストは $\alpha-\mathrm{CD}$ 環の内外に $1 つ$

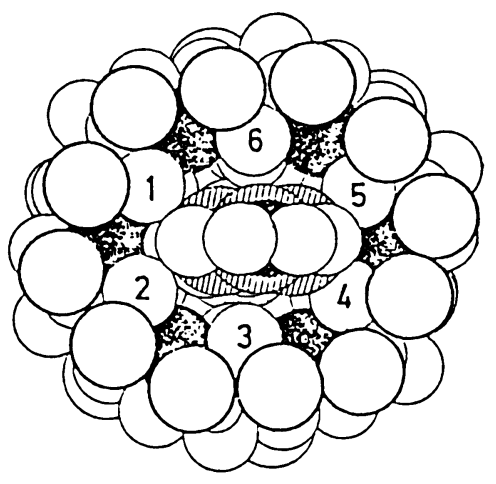

第 9 图 $\alpha-\mathrm{CD}$ ・ $p$-ヨウ素アニリン包接 化合物に見られる棈円形の $\alpha-C D$

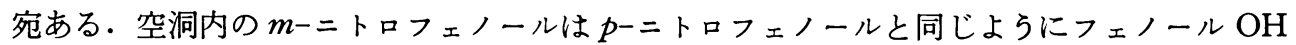
基を $\mathrm{O}(2), \mathrm{O}(3)$ 側から環外につき出し, ベンゼン環部分を空洞内に包接させているが, $p$ 体よりは浅く，ゆるくとり込まれていて，その様式は $\alpha-\mathrm{CD}$ メチルオレンジ $\mathrm{Na}$ 塩 ${ }^{17)}$ の $\mathrm{N}$, $\mathrm{N}$-ジメチルアミノフェニル残基と同じである. この $p$-体及び $m$-体の分子構造から， $\alpha-\mathrm{CD}$ • $2 \mathrm{H}_{2} \mathrm{O}+$ ゲスト $\rightleftharpoons \alpha-\mathrm{CD} ・$ ゲスト $+2 \mathrm{H}_{2} \mathrm{O}$ 系でのエンタルピー変化を $\Delta \mathrm{H}^{\mathrm{s}}$ (溶媒和), $\Delta \mathrm{H}^{\mathrm{c}}$ ( ンフォメーション変化), $\Delta \mathrm{H}^{\mathrm{i}}$ (相互作用)にわけて計算し第 3 表の結果 ${ }^{23)}$ を得ている。 $\Delta \mathrm{H}$ は $p$-体の方が $m$-体より 3 倍も大きく, より安定であり, 相互作用エネルギーが大きく寄与 している. 更に酥酸フェニルのカルボニル炭素の位置を推定し, これと $\alpha-\mathrm{CD}$ の二級水酸了 ニオンとの距離を計算すると， $m$-体の方が $p$-体よりも短く,かつ $m$-体はゆるく包接されて いるので $m$-体の反応が $p$-体より速く進行すると説明されている．同じゲスト分子を用いて も，ホストが $\alpha-\mathrm{CD}$ から $\beta-\mathrm{CD}$ に変ると包接化合物の構造が大きく変ることが明らかになっ た.このことは今迄の $\alpha-C D$ にいての考察が $\beta-C D$ に決ずしもあてはまらないことを意

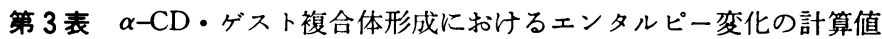
$(\mathrm{kcal} / \mathrm{mol})^{28)}$

\begin{tabular}{|c|c|c|c|c|}
\hline$\alpha-\mathrm{CD}$ ・ゲスト & $\Delta \mathrm{H}^{\mathrm{s}}$ & $\Delta \mathrm{H}^{\mathrm{c}}$ & $\Delta \mathrm{H}^{\mathrm{i}}$ & $\Delta \mathrm{H}$ \\
\hline 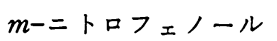 & 1.64 & -0.69 & -4.61 & -3.66 \\
\hline 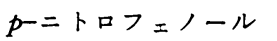 & 1.42 & 0.92 & -13.68 & -11.34 \\
\hline
\end{tabular}

24. $1-60$ 
味する. $\beta-\mathrm{CD} \cdot p-\exists ウ$ 素フェノール ${ }^{30)}$ は $\beta-\mathrm{CD}$. $n$-プロパノール ${ }^{30)}$ と同形であるが, $\beta-C D$ ・水 和物 ${ }^{25)}$ と異なり空間群は P1, $\beta-C D$ は headto-head の二量体 (第 10 図) でその中に 3 分子 のp-ヨウ素フェノールを包接している， $\alpha-\mathrm{CD}$ ・p-ヨウ素フェノール21) と同様, ヨウ素が空洞 内部に入っているがフェノール $\mathrm{OH}$ 基は $\alpha-\mathrm{CD}$ とは逆の $\mathrm{O}(6)$ 側に向いている. $\beta-\mathrm{CD}$ 二量体 は真中に第 3 番目の $p$-ヨウ素フェノ.ールを包 接している.これと同様の構造が $\beta-C D-3,4-\neq$ シリジン ${ }^{32)}$ においても見られアミノ基が $\mathrm{O}(6)$ 側からつき出ている. $\beta-C D:$ ホスト $=2: 3$ の包 接化合物は $\beta-C D \cdot n-フ^{\circ}$ パノール $\left.30 \sim 31\right)$ にも見 られている・ $\beta-\mathrm{CD} \cdot p$-エチルアニリン ${ }^{33)}($ 第11 図)と $p$-ヨウ素アニリン ${ }^{33)}$ とは同形で空間群は

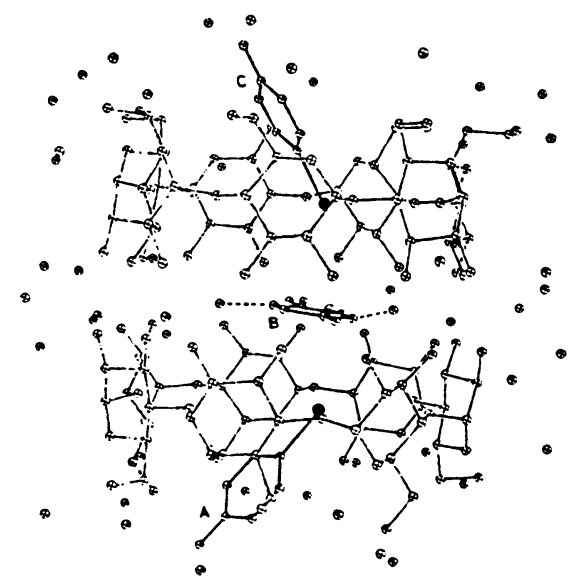

第10図 $\beta$-CD・p-ヨウ素フェノールの分 子構造 (黒丸はョウ素原子).

$\mathrm{P} 2$ である. ホスト:ゲスト $=2: 2$ で $\beta-\mathrm{CD}$ は head-to-head の二量体構造の内部に 2 分子の $p$-エチルアニリンを包接している.ゲストのアミノ基は $\alpha-\mathrm{CD}$ の場合と同様 $\mathrm{O}(2), \mathrm{O}(3)$ 側 よりはみ出しているが片方のゲストのアミノ基は空洞内部に埋れている．解析例が少ないの で結論は出せないが， $\beta-C D$ の場合は，これらのゲスト分子が充媜するには広すぎる空洞を

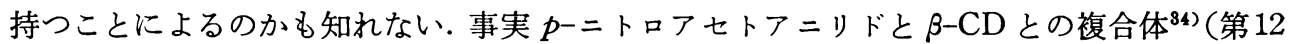
図）では空間群 P $1, \beta-C D$ は head-to-head の二量体で，その中にアセトアニリドの加水分 解機構を支持する位置に $\mathrm{CH}_{3} \mathrm{CONH}$ - 基がきた構造が報告されており，この $m$-置換体の結 果が待たれている.

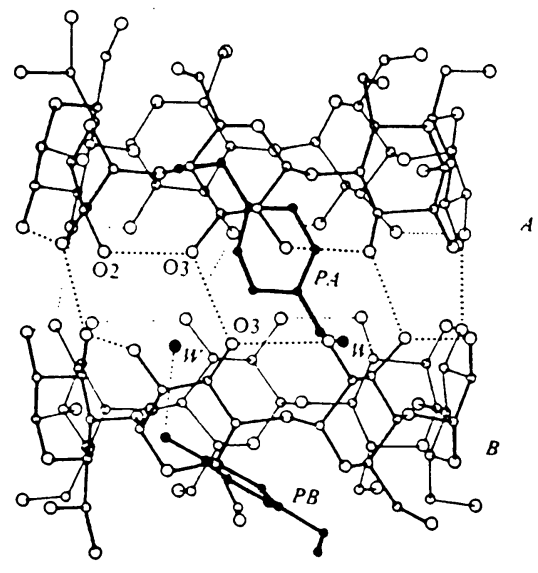

第11図 $\beta-\mathrm{CD} p$-エチルアニリンの 分子構造.

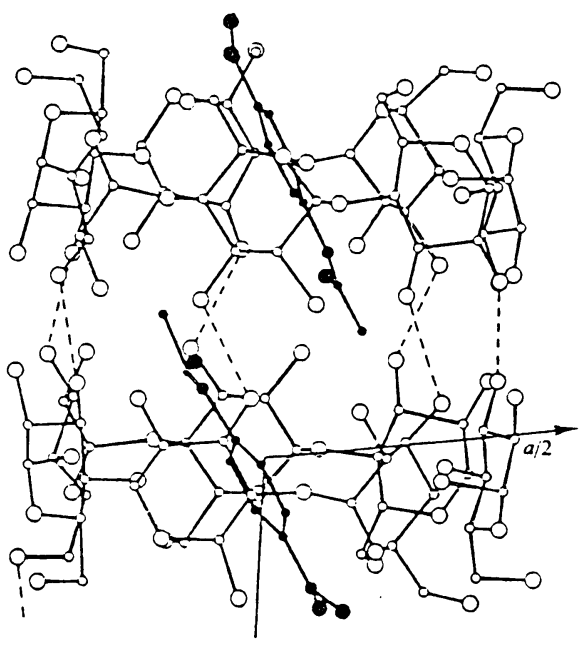

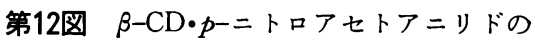
分子構造.

\section{5. ヨウ素-デンプン反応モデルとして}

$5 \times 10^{-2} \mathrm{M}$ 金属ヨウ化物とヨウ素 $\left(\mathrm{I}^{-} / \mathrm{I}_{2}>1.3 / 1\right)$ を含む $\alpha-\mathrm{CD}$ 高温飽和水溶液から $\alpha-\mathrm{CD}$. 


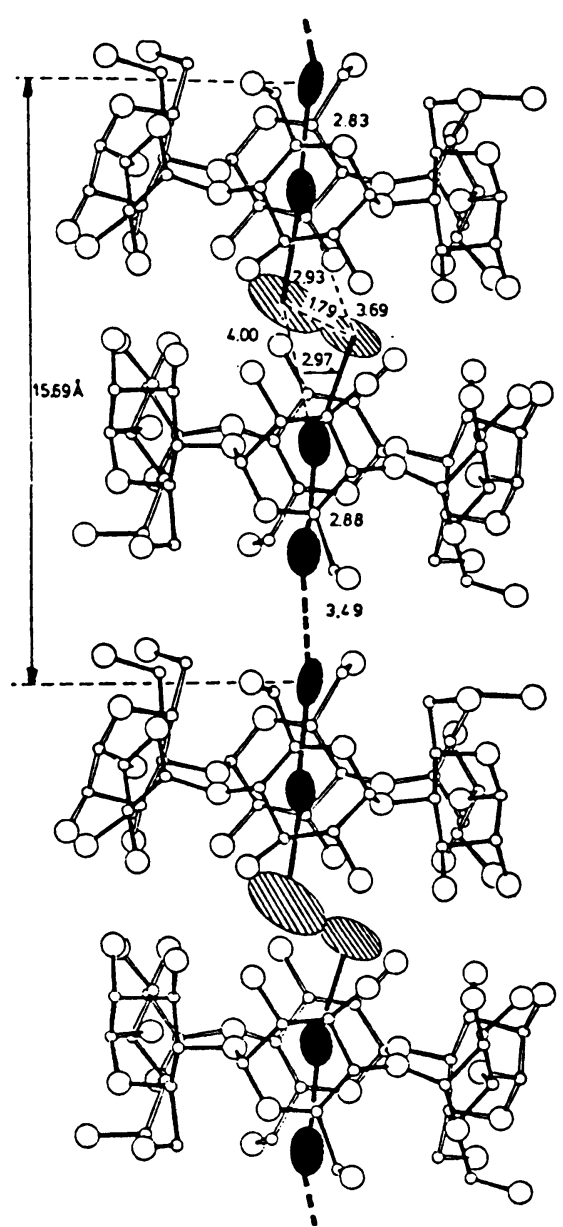

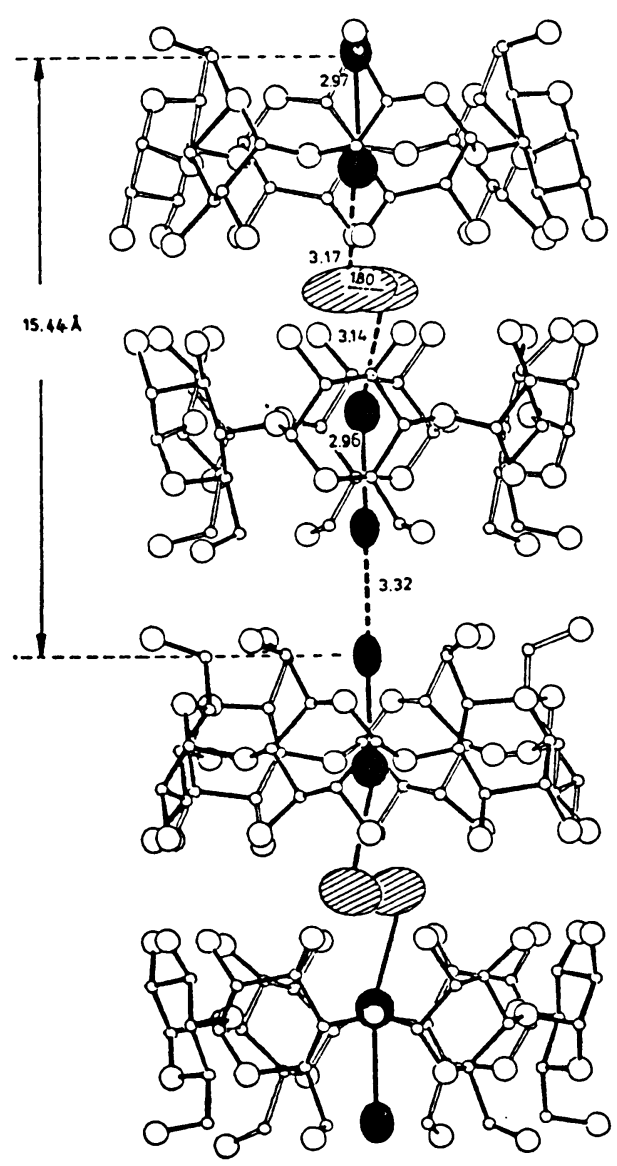

第14图 $(\alpha-\mathrm{CD})_{2} \cdot \mathrm{Cd}_{0.5} \cdot \mathrm{I}_{5} \cdot 27 \mathrm{H}_{2} \mathrm{O}$ の分子構造

第13図 $(\alpha-\mathrm{CD})_{2} \cdot \mathrm{LiI}_{3} \cdot \mathrm{I}_{2} \cdot 8 \mathrm{H}_{2} \mathrm{O}$ の分子構造 ポリヨウ化物複合体結晶を得る.このうち三斜晶系に属する $\left.(\alpha-\mathrm{CD})_{2} \cdot \mathrm{LiI}_{8} \cdot \mathrm{I}_{2} \cdot 8 \mathrm{H}_{2} \mathrm{O}^{37}\right)$ と正 方晶系に属する $\left.(\alpha-\mathrm{CD})_{2} \cdot \mathrm{Cd}_{0.5} \cdot \mathrm{I}_{5} \cdot 27 \mathrm{H}_{2} \mathrm{O}^{87}\right)$ の結晶構造が重要である. 三斜晶系に属するの は $\mathrm{Li}^{+}, \mathrm{Na}^{+}, \mathrm{Tl}^{+}$にのみ得られ格子定数からは六方晶系に近い。構造は第 13 図に示すように $\alpha-\mathrm{CD} 2$ 分子が $7^{\circ}$ 傾いて head-to-head に向いあった二量体を単位として c 軸方向 $15.69 \AA$ の周期で無限に連なっている， $\alpha-C D$ は無歪大環状構造をとり $\mathrm{O}(6)$ はすべて環外に飛び出 している. 二量体間は $\mathrm{O}(2) \cdots \mathrm{O}\left(3^{\prime}\right), \mathrm{O}\left(2^{\prime}\right) \cdots \mathrm{O}(3)$ 水素結合で結ばれている. $\mathrm{G} 1^{\prime}$ と $\mathrm{G} 2$ との 間には $\mathrm{O}(2) \cdots \mathrm{O}\left(3^{\prime}\right)$ 水素結合に加えて $\mathrm{Li}^{+}$イオンが $\alpha-\mathrm{CD}$ 環の外側から $\mathrm{O}(2), \mathrm{O}(3), \mathrm{O}\left(2^{\prime}\right)$, $\mathrm{O}\left(3^{\prime}\right)$ 及び水分子 $\mathrm{W}(8)$ に正方錐体配位結合をして二量体構造をより安定にしている. 問題 のポリョウ素鎖については， $\boldsymbol{\alpha}-\mathrm{CD}$ の広い入口即ち $\mathrm{O}(2), \mathrm{O}(3)$ の間で図中斜線をつけたョ ウ素が 69:31 の占有率で 2 箇所に disorder しており，その鎖は少しジグザグ状である． disorder したヨウ素間は $1.79 \AA$ で同時には存在できないので, ポリヨウ素単位としては $\mathrm{I}_{3}{ }^{-} \cdot \mathrm{I}_{2}$ 或いは $\mathrm{I}_{2} \cdot \mathrm{I}_{3}{ }^{-}$が考えられる. $\mathrm{I}_{3}{ }^{-}, \mathrm{I}_{2}$ でのヨウ素の共有結合長はそれぞれの標準値 2.9 及び $2.67 \AA$ より何れも長い. その分だけ $\mathrm{I}_{8}{ }^{-}$と $\mathrm{I}_{2}$ 間の距離が近ずきファンデルワールス半径の 和 $4.3 \AA$ より短い $3.7 \AA$ となり， $\mathrm{I}_{3}-$ と $\mathrm{I}_{2}$ 間での電荷移動相互作用が考えられる．次に正方 晶系, $\mathrm{P}_{2} 2_{1} 2$ に属する $(\alpha-\mathrm{CD})_{2} \cdot \mathrm{Cd}_{0.5} \cdot \mathrm{I}_{5} \cdot 27 \mathrm{H}_{2} \mathrm{O}$ の構造 (第 14 図)についてのべる. $\alpha-\mathrm{CD}$ 
は head-to-head 二量体構造をしているが怙互いに $13^{\circ}$ 回転した形となっていて二量体のか み合せが深くなり $\mathrm{c}$ 軸周期は $15.44 \AA$ と三斜晶系型より短い. 水素結合の様式も異なり二量 体は $\mathrm{O}(2) \cdots \mathrm{O}\left(2^{\prime}\right)$ 及び $\mathrm{O}(3) \cdots \mathrm{O}\left(3^{\prime}\right)$ 水素結合で直接結ばれ $\mathrm{O}(6)$ 水酸基側では次の二量体 との間で $\mathrm{O}(6) \cdots \mathrm{O}\left(6^{\prime}\right)$ 水素結合がみられる. $\mathrm{Cd}^{2+}$ は $\alpha-\mathrm{CD}$ の水酸基との間の直接の配位は なくすべて 6 個の結晶水との間で 6-配位結合をしている.この水は占有率 $100 \%$ で水和の殻 を形成しているが, 中の $\mathrm{Cd}^{2+}$ の占有率は数\%にすぎない. $\mathrm{Li}^{+}$複合体と同様に 5 つのヨウ素 原子が $\alpha-\mathrm{CD}$ 二量体中に存在している。このうち 4 個は 42 軸上にあり, 二量体の接合体に ある 1 つのヨウ素のみが 50:50 の占有率で disorder している. $\mathrm{Li}^{+}$の場合と同様 $\mathrm{I}_{3}{ }^{-}, \mathrm{I}_{2}$ で説 明することも出来るが，この場合はむしろ disorder したョウ素を中心にして直鎖状 $\mathrm{I}_{5}$ - と見 做すことにする．共鳴ラマン及びメスバゥアー効果による研究38) でデンプン中のヨウ素は $\mathrm{I}_{5}$-であることが示されている．ホスト $\alpha-\mathrm{CD}$ とゲストヨウ素の間には明らかに特異性が見 られる. 即ち disorder のないヨウ素の位置は $\mathrm{Li}^{+}, \mathrm{Cd}^{2+}$, 及び $\alpha-\mathrm{CD} \cdot \mathrm{I}_{2} \cdot 2 \mathrm{H}_{2} \mathrm{O}^{39}$ ) 場合でも すべて $\mathrm{O}(4)$ 平面, $\mathrm{C}(6)$ 平面近くに存在するので $\alpha-\mathrm{CD}$ とポリョウ素間には特異的相互作用 が働いていると思われる.この相互作用は電荷移動, 双極子-双極子或いはアミロース・ヨウ 素青色複合物で仮定されたヨウ素と $\mathrm{O}(4)$ 原子間とのファンデルワールス相互作用の何れに も㷌属できない.ところが分極し易いヨウ素と C (3)-H, C (5)-H メチン基との接触は 3.24 〜 $4.03 \AA$ で, ファンデルワールス距離 $\mathrm{H} \cdots \mathrm{I}=3.3 \AA$ にあり, 炭化水素溶液中のヨウ素と同 様 H…I の分散力が $\alpha-\mathrm{CD}$ ・゚リ ヨウ素の安定化に寄与していると考える.

\section{6. おわりに}

$\mathrm{CD}$ が何故に低分子有機化合物やポリヨウ素と分子複合体をつくるのか？ 包接過程にお ける推進力とは何か？といら問に対し以前から提証されてきたホスト・ゲスト間の疎水結 合, 双極子一双極子相互作用及びロンドン分散力に加えて, X線解析より CD 環の歪ェネル ギーの解消, ホストとゲストとの水素結合, 空洞内の活性化されている水の作用が提案され

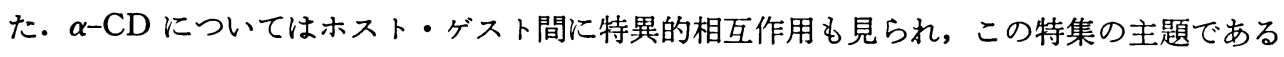

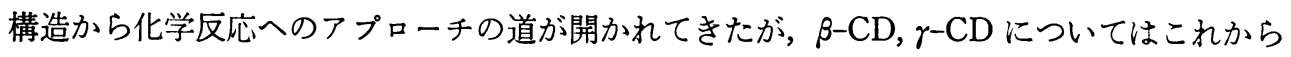
の感が深く今後の研究が大いに期待される.

\footnotetext{
文献

1) M. L. Bender and M. Komiyama : 平井英史, 小宮山真訳. “シクロデキストリンの化学”, 学 会出版センター, 東京 (1979).

2) W. Saenger : Environmental Effects on Molecular Structure and Properties, Ed. by B. Pullman, p. 265, D. Reidel, Netherland (1976).

3) 原田一明: 測粉科学, 26, 198 (1979).

4) 御船昭, 島淳之: 有機合成化学, 35, 116 (1977).

5) W. Saenger : Angew. Chem. Int. Ed. Engl. 19, 344 (1980).

6) R. L. van Etten, J. F. Sebastian, G. A. Clowes and M. L. Bender : J. Am. Chem. Soc. 89, 3242 (1967).

7) P. C. Manor and W. Saenger : J. Am. Chem. Soc. 96, 3630 (1974).

8) K. Lindner : Dissertation Universität Göttingen (1980).

9) K. K. Chacko and W. Saenger: J. Am. Chem. Soc. 103, 1708 (1981).

10) W. Saenger : Nature, 279, 343 (1979).
} 
11) W. Saenger and K. Lindner : Angew. Chem. Int. Ed. Engl. 19, 398 (1980).

12) W. Saenger and M. Noltemeyer : Angew. Chem. Int. Ed. Engl. 13, 552 (1974).

13) B. Hingerty and W. Saenger: J. Am. Chem. Soc. 98, 3357 (1976).

14) W. Saenger, R. K. McMullan, J. Fayos and D. Mootz: Acta Cryst. B 30, 2019 (1974).

15) A. Hybl, R. E. Rundle and D. E. Williams : J. Am. Chem. Soc. 87, 2779 (1965).

16) R. Tokuoka, M. Abe, K. Matsumoto, K. Shirakawa, T. Fujiwara and K. Tomita, Acta Cryst. B 37, 445 (1981).

17) K. Harata : Bull. Chem. Soc. Jpn. 49, 1493 (1976).

18) K. Harata: Bull. Chem. Soc. Jpn. 49, 2066 (1976).

19) K. Harata: Bull. Chem. Soc. Jpn. 50, 1259 (1977).

20) W. Saenger, K. Beyer, and P. C. Manor : Acta Cryst. B 32, 120 (1976) ; K. Harata : Bull. Chem. Soc. Jpn. 48, 2409 (1975).

21) K. Harata : Carbohydr. Res. 48, 265 (1976).

22) K. Harata : Bull. Chem. Soc. Jpn. 50, 1416 (1977).

23) K. Harata, H. Uedaira and J. Tanaka : Bull. Chem. Soc. Jpn. 51, 1627 (1978).

24) K. Harata : Bull. Chem. Soc. Jpn. 53, 2782 (1980).

25) K. Lindner and W. Saenger : Angew. Chem. Int. Ed. Engl. 17, 694 (1978).

26）山崎真利, 戸水由貴子, 徳田良二, 藤原隆二, 冨田研一, 松尾隆祐, 菅宏 : 日本結晶学会昭和 56 年度年会発表 (九州大学).

27) K. Lindner and W. Saenger : Carbohydr. Res. Submitted (1981).

28) R. Tokuoka, M. Abe, T. Fujiwara, K. Tomita and W. Saenger : Chem. Lett. 1980 (491).

29) J. A. Hamilton, M. N. Sabesan, L. K. Steinrauf and A. Geddes : Biochem. Biophys. Res. Comm. 73, 659 (1976).

30) J. J. Stezowski, K. H. Jogun, E. Eckle and K. Barteles : Nature, 274, 617 (1978).

31) K. H. Jogun and J. J. Stezowski : Nature, 278, 667 (1979).

32) 藤原隆二, 徳田良二, 富田研一: 日本結晶学会昭和56年度年会発表 (九州大学).

33) R. Tokuoka, T. Fujiwara and K. Tomita : Acta Cryst. B 37, 1158 (1981).

34) M. M. Harding, J. M. Maclennan and R. M. Paton : Nature, 274, 621 (1978).

35) J. M. Maclennan and J. J. Stezowski : Biochem. Biophys. Res. Comm. 92, 926 (1980).

36) K. Lindner and W. Saenger : Biochem. Biophys. Res. Comm. 92, 933 (1980).

37) M. Noltemeyer and W. Saenger: J. Am. Chem. Soc. 102, 2710 (1980).

38) R. C. Teitelbaum, S. L. Ruby and T. J. Marks : J. Am. Chem. Soc. 102, 3322 (1980).

39) R. K. McMullan, W. Saenger, F. Fayos and D. Mootz: Carbohydr. Res. 31, 211 (1973). 